\title{
OPEN Effects of nitrogen fertilization on protein and carbohydrate fractions of Marandu palisadegrass
}

\author{
Rhaony Gonçalves Leite ${ }^{1}$, Abmael da Silva Cardoso ${ }^{1 凶}$, Natália Vilas Boas Fonseca ${ }^{1}$, \\ Maria Luisa Curvelo Silva ${ }^{1}$, Luís Orlindo Tedeschi ${ }^{2}$, Lutti Maneck Delevatti ${ }^{1}$, \\ Ana Cláudia Ruggieri ${ }^{1} \&$ Ricardo Andrade Reis ${ }^{1}$
}

The effects of nitrogen $(\mathrm{N})$ fertilization levels on protein and carbohydrate fractions in Marandu palisadegrass pasture [Urochloa brizantha (Hochst. ex A. Rich.) R.D. Webster] were investigated in a pasture over five years. The experimental design was completely randomized with four levels of $\mathrm{N}(0$, 90,180 , and $270 \mathrm{~kg} \mathrm{~N} \mathrm{ha}^{-1}$, as urea) for five years, and with three replicates. The study was conducted in a continuously stocked pasture during the forage growing season (December to April) in a tropical region. The effects of $\mathrm{N}$ fertilization were similar across the five years. With increasing $\mathrm{N}$ fertilization, the concentrations of crude protein (CP) increased from 103 to $173 \mathrm{~g} \mathrm{~kg}^{-1}(P<0.001)$, soluble fractions (Fraction A + B1) increased from 363 to $434 \mathrm{~g} \mathrm{~kg}^{-1}$ of total CP $(P=0.006)$; neutral detergent fiber (NDF) decreased from 609 to $556 \mathrm{~g} \mathrm{~kg}^{-1}(P=0.037)$; indigestible NDF $(P=0.046)$, potentially degradable neutral detergent fiber $(P=0.037)$, and acid detergent fiber decreased $(P=0.05)$, and total digestible nutrient (TDN) increased $(P<0.001)$. Increasing $N$ fertilization decreased the concentrations of Fraction $C(P=0.014)$ and total carbohydrates $(P<0.0001)$, and increased $C P$ :organic matter digestibility $(P<0.01)$. Concentrations of neutral detergent fiber free of ash and protein $(P=0.003)$, indigestible neutral detergent fiber $(P<0.001)$, neutral detergent fiber potentially degradable $(P=0.11), C P(P<0.001)$, Fraction A $+B 1(P<0.001)$, Fraction B2 $(P<0.001)$, Fraction $\mathrm{B} 3(P<0.01)$, and non-structural carbohydrates differed $(P<0.001)$ across years. Therefore, $N$ fertilization can be used to increase $C P$, soluble protein, and TDN.

Grassland areas are becoming increasingly important for animal production due to the increase in cattle production in Latin America, Africa, and Asia ${ }^{1}$. Areas in which tropical grasses predominate are known to have forage with low protein concentrations and digestibility ${ }^{2}$. This low nutritional value of tropical grasses could be due to poor pasture management (e.g., inappropriate pasture height), overgrazing, an absence or a low level of fertilization, and poor soil fertility ${ }^{3}$. Furthermore, feed and fodder scarcity is regarded as a general problem for low livestock productivity in tropical areas. However, adequate information regarding the nutritional value of grasses in terms to improve the profile of protein fractions with fertilization is lacking.

Nitrogen $(\mathrm{N})$ fertilization can increase forage production and nutritional value in tropical regions ${ }^{4}$. $\mathrm{N}$ fertilizers can increase forage production and affect forage quality ${ }^{4-8}$. In grasslands, the concentration of forage protein, soluble carbohydrates, and cell wall components are essential because, when consumed by the animals, these are supplied to the rumen microbes and therefore affect animal maintenance and production ${ }^{9-11}$. Protein and carbohydrate concentrations of grasses and their digestibility are affected by fertilization, species, stage of maturity, management, and climatic factors ${ }^{12-14}$. These climatic factors e.g. precipation may vary along the year and therefore can affect the effect of $\mathrm{N}$ fertilization on nutritive value of grasses.

Particular fractions of proteins and carbohydrates are important; therefore, a system that classifies fractions based on their solubility has been proposed. The Cornell Net Carbohydrate and Protein System (CNCPS) was developed to account for nutrient fractionation. It was initially developed in a series of four papers ${ }^{15-18}$ and has received many updates and modifications ${ }^{10,11}$. The CNCPS is not the only mathematical model to adopt the fractionation of nutrients to improve diet evaluation ${ }^{19}$. In the CNCPS, the detergent fiber system of feed analysis is used to fractionate carbohydrates into fiber carbohydrates [neutral detergent fiber (NDF) and lignin] and non-fibrous carbohydrates (NFC; soluble sugars, starch, and pectin). Proteins are divided into fractions based on their fermentation characteristics (Fraction $\mathrm{A}=$ non-protein nitrogen, Fraction $\mathrm{B} 1$ = easily-degradable

${ }^{1}$ Department of Animal Sciences, São Paulo State University, Jaboticabal, SP 14884-900, Brazil. ${ }^{2}$ Department of Animal Science, Texas A\&M University, College Station, TX 77843-2471, USA. ${ }^{\otimes}$ email: abmael.cardoso@unesp.br 


\begin{tabular}{|c|c|c|c|c|c|}
\hline \multirow[b]{2}{*}{ Variable } & \multicolumn{4}{|c|}{ Nitrogen dose $\left(\mathrm{kg} \mathrm{N} \mathrm{ha}^{-1}\right)$} & \multirow[b]{2}{*}{ Effect $^{1}$} \\
\hline & 0 & 90 & 180 & 270 & \\
\hline $\mathrm{TC}$ & $783.7(15.6)$ & $760.8(16.0)$ & $742.1(15.4)$ & $721.3(17.8)$ & Linear \\
\hline NFC & $94.4(4.5)$ & $90.8(5.2)$ & $90.1(6.6)$ & $85.9(8.1)$ & ns \\
\hline apNDF & $609.3(7.0)$ & $590.0(6.9)$ & $572.0(5.7)$ & $556.4(5.6)$ & Linear \\
\hline iNDF & $187.8(2.3)$ & $177.1(2.4)$ & $174.1(1.8)$ & $156.5(1.5)$ & Linear \\
\hline NDFpd & $421.5(8.2)$ & $413.0(6.7)$ & $397.9(7.2)$ & $399.9(8.1)$ & Quadratic \\
\hline $\mathrm{ADF}$ & $327.0(6.5)$ & $307.0(6.9)$ & $301.6(7.8)$ & $294.7(6.5)$ & Linear \\
\hline Lignin & $87.3(2.1)$ & $85.0(2.4)$ & $83.3(2.5)$ & $86.0(1.9)$ & ns \\
\hline TDN & $629.9(11.4)$ & $636.0(10.3)$ & $638.5(15.6)$ & $642.2(13.4)$ & Linear \\
\hline $\begin{array}{l}\text { CP:DOM }\left(\mathrm{g} \mathrm{CP} \mathrm{kg}^{-1}\right. \\
\text { DOM) }\end{array}$ & $125(7)$ & $152(8)$ & $174(8)$ & $195(10)$ & Linear \\
\hline $\mathrm{CP}$ & $103.2(10.1)$ & $128.6(11.3)$ & $150.0(14.4)$ & $172.8(14.3)$ & Linear \\
\hline $\begin{array}{l}\text { Fraction } \mathrm{A}+\mathrm{B} 1\left(\mathrm{~g} \mathrm{~kg}^{-1}\right. \\
\mathrm{CP})\end{array}$ & $363.3(8.2)$ & $369.0(7.2)$ & $406.1(8.1)$ & $433.2(7.2)$ & Linear \\
\hline Fraction $\mathrm{C}\left(\mathrm{g} \mathrm{kg}^{-1} \mathrm{CP}\right)$ & $125.0(3.5)$ & $103.7(2.8)$ & \begin{tabular}{|l|l}
$101.9(3.7)$ \\
\end{tabular} & $98.3(2.9)$ & Linear \\
\hline
\end{tabular}

Table 1. Average chemical composition for Marandu palisadegrass ( $\mathrm{g} \mathrm{kg}^{-1}$ dry matter) affected by nitrogen dose. ${ }^{1}$ Orthogonal polynomial effect of $\mathrm{N}$ doses. Effect probability (apNDF, $P<0.0001$; iNDF, $P=0.046$; NDFpd, $P=0.037$; ADF, $P=0.05$; Lignin, $P=0.19$; TDN, $P<0.0001$; TC, $P<0.0001$; $\mathrm{CP}$ :DOM, $P<0.01$; $\mathrm{CP}$, $P<0.001$; Fraction $\mathrm{A}+\mathrm{B} 1, P=0.006$; and Fraction $\mathrm{C}, P=0.014)$. Within parentheses is the standard error of the means $(\mathrm{SEM} ; \pm)$

protein, Fraction B2 = intermediately-degradable protein, Fraction B3 = slowly-degradable protein, and Fraction $\mathrm{C}=$ non-degradable and unavailable to the animal), as described by Sniffen et al. ${ }^{17}$. Therefore, to improve the nutritional value of grasses, it is essential to increase $\mathrm{CP}$ and reduce fiber concentrations, and identify how the fractions are available for ruminal degradation and microbial growth. Tedeschi and Fox ${ }^{10,11}$ described additional modifications to the protein fractionation regarding the use of tungstic acid versus trichloroacetic acid to more consistently separate the non-protein fraction.

To apply the CNCPS to forages, it is necessary to characterize carbohydrates and $\mathrm{N}$ fractions ${ }^{10,11}$. Previous research has characterized protein fractions of various forage species from temperate areas ${ }^{12,20}$, including warm grasses [such as bermudagrass, stargrass, and bahiagrass] ${ }^{21}$ and guinea grass ${ }^{22}$. However, information related to the effects of $\mathrm{N}$ fertilization and annual changes in the carbohydrate and protein fractions of Brachiaria is limited. Furthermore, Brachiaria is the most utilized forage for cattle production in tropical areas, and the effects of $\mathrm{N}$ fertilization may vary among species and regions.

Thus, we studied the effect of $\mathrm{N}$ fertilization and year seasonality on carbohydrate and protein fractions of Marandu palisadegrass. We hypothesized that the concentrations of $\mathrm{CP}$ and Fraction A would increase with $\mathrm{N}$ fertilization level, whereas the fibrous carbohydrate fractions would decrease. Additionally, we hypothesized that the $\mathrm{N}$ fertilization effect on carbohydrates and protein fractions would vary with year.

\section{Results and discussion}

In our studies with Marandu palisadegrass, a grazing management strategy with continuous stocking where 95\% of the light is intercepted by the canopy resulted in forage at a height of $25 \mathrm{~cm}$, a high green leaf proportion, and low amounts of dead material during the growing season ${ }^{23,24}$. The use of $\mathrm{N}$ fertilization ${ }^{4}$, different stocking rates, and supplementation ${ }^{25-27}$ are crucial for obtaining forage with a high nutritional value, resulting in a high weight gain per animal and area, and a reduction in slaughter age and greenhouse gas emissions. In the present study we did not find any interection $\mathrm{N}$ doses with years. Therefore, only the significative effects of $\mathrm{N}$ fertilization or variation within year are presented and discussed.

Total and non-fibrous carbohydrates and total digestible nutrients. Total carbohydrate concentrations decreased linearly with increasing $\mathrm{N}$ levels $(P<0.01$; Table 1$)$. Nitrogen fertilization increases cell content concentrations (soluble fractions) and changed the sugar composition and bonds established between them in the cell wall ${ }^{28}$. Therefore, the reduction in TC represents the reductions observed in the NDF and ADF fractions (Table 1). The fibrous compounds in forage decrease with increasing $\mathrm{N}$ levels because this nutrient stimulate the growth of new tissues ${ }^{29}$. In the present study, we managed the pasture to reduce stem growth. A sward height of $25 \mathrm{~cm}$ stimulates tillering and growth of new tissues ${ }^{24}$.

NFC varied according to the experimental year $(P<0.01$; Table 2$)$. The NFC fraction can be rapidly degraded in the rumen, and is necessary to maintain adequate carbohydrate and protein degradation synchrony, and promote adequate microbial growth ${ }^{17}$. Variations in climatic conditions, such as precipitation, alter the production of leaves and stems, and, consequently, cause changes in the concentrations of soluble sugars, starches, and pectins $^{22}$. Our results are in agreeance with those of Santos et al..$^{22}$, who observed high NFC when the highest precipitation occurred. Another climatic variable related to NFC is the sunlight, which affects the amount of glucose formed during photosynthesis ${ }^{30}$. Only the year affected NFC (Table 2). The highest NFC occurred in 


\begin{tabular}{|l|l|l|l|l|l|l|}
\hline \multirow{2}{*}{ Variable } & \multicolumn{4}{|l}{ Experimental year } & \multirow{2}{*}{} \\
\cline { 2 - 6 } & $\mathbf{2 0 1 5}$ & $\mathbf{2 0 1 6}$ & $\mathbf{2 0 1 7}$ & $\mathbf{2 0 1 8}$ & $\mathbf{2 0 1 9}$ & Effect $^{1}$ \\
\hline apNDF & $589.6(5.4)$ & $541.3(5.7)$ & $605.4(6.7)$ & $620.4(4.9)$ & $552.9(4.7)$ & Cubic $^{1}$ \\
\hline iNDF & $116.0(1.0)$ & $167.4(6.0)$ & $215.4(7.6)$ & $204.2(4.6)$ & $166.2(9.6)$ & Quadratic \\
\hline NDFpd & $473.6(3.9)$ & $373.9(7.1)$ & $390.0(5.6)$ & $416.3(5.2)$ & $386.6(3.4)$ & ns \\
\hline ADF & $298.2(2.8)$ & $254.4(2.3)$ & $302.7(3.1)$ & $361.5(3.1)$ & $312.3(2.9)$ & Cubic \\
\hline OM & $911.5(1.9)$ & $922.0(2.3)$ & $919.0(2.2)$ & $911.9(2.0)$ & $908.6(1.9)$ & Quadratic \\
\hline NFC & $136.3(10.7)$ & $246.6(13.2)$ & $162.5(14.2)$ & $134.2(9.7)$ & $170.6(15.3)$ & Cubic \\
\hline CP & $123.1(12.1)$ & $130.1(11.6)$ & $127.5(9.8)$ & $142.2(13.5)$ & $170.2(16.5)$ & Linear \\
\hline $\begin{array}{l}\text { Fraction A+ B1 (g } \\
\left.\mathrm{kg}^{-1} \mathrm{CP}\right)\end{array}$ & $325.4(3.3)$ & $302.1(3.6)$ & $367.9(4.1)$ & $382.9(3.8)$ & $586.0(3.2)$ & Linear \\
\hline $\begin{array}{l}\text { Fraction B2 (g } \\
\left.\mathrm{kg}^{-1} \mathrm{CP}\right)\end{array}$ & $282.5(2.2)$ & $245.3(2.5)$ & $284.0(2.8)$ & $177.8(2.0)$ & $166.6(2.2)$ & Quadratic \\
\hline $\begin{array}{l}\text { Fraction B3 (g } \\
\left.\mathrm{kg}^{-1} \mathrm{CP}\right)\end{array}$ & $314.0(3.4)$ & $340.4(3.6)$ & $229.6(3.7)$ & $264.5(2.8)$ & $196.1(2.9)$ & Quadratic \\
\hline
\end{tabular}

Table 2. Average chemical composition for Marandu palisadegrass ( $\mathrm{g} \mathrm{kg}^{-1}$ dry matter) affected by year. ${ }^{1}$ Orthogonal polynomial effect of $\mathrm{N}$ doses. Effect probability (apNDF, $\mathrm{P}=0.003$; iNDF, $P<0.001$; NDFpd, $P=0.11$; ADF, $P<0.0001$; NFC, $P<0.001$; $\mathrm{CP}, P<0.001$; Fraction $\mathrm{A}+\mathrm{B} 1, P<0.001$; Fraction $\mathrm{B} 2, P<0.001$; and Fraction $\mathrm{B} 3, P<0.01)$. Within parentheses is the standard error of the means $(\mathrm{SEM} ; \pm)$.
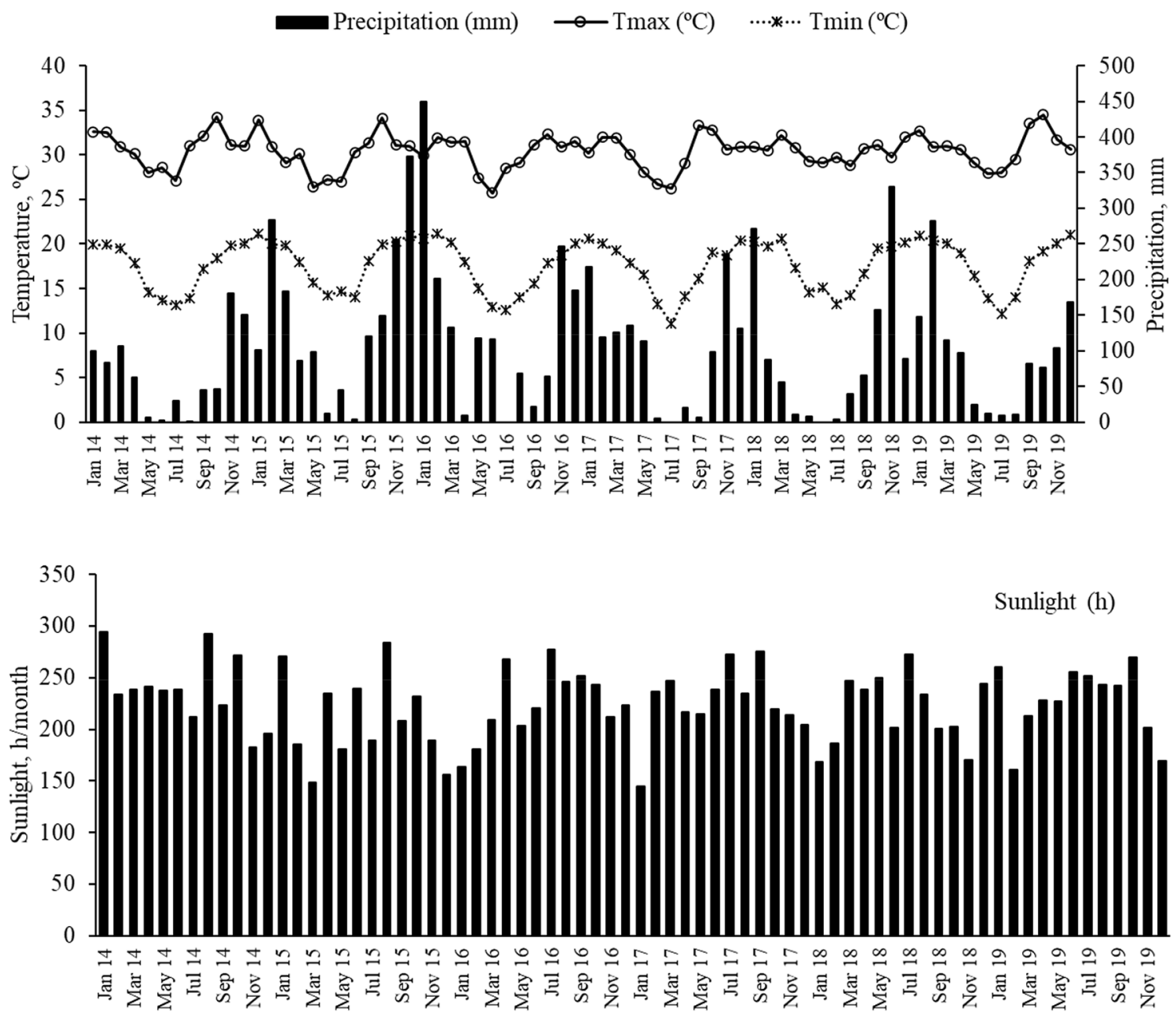

Figure 1. Precipitation, temperature, and sunlight from 2015 to 2019 at the experimental site at the São Paulo State University Jaboticabal, São Paulo, Brazil. 
2016, when the highest precipitation and lowest sunlight hours were recorded (Fig. 1 and Table 2). Greater sunlight increases the photosynthetic rate, which stimulates stem elongation by promoting cell growth. Cloudy and warm days stimulate the growth of new tissues ${ }^{29}$.

Increasing $\mathrm{N}$ fertilization increased the TDN concentration $(P<0.01$; Table 1$)$. The TDN fraction is similar to $\mathrm{OM}$ in terms of digestibility and is usually found at a concentration of $60 \%$ in tropical grasses ${ }^{28}$. However, it increased on average from 62 to $65 \%$ in our study as $\mathrm{N}$ fertilization increased from 0 to $270 \mathrm{~kg} \mathrm{~N} \mathrm{ha}^{-1}$. Increases in variables related to forage digestibility in response to $\mathrm{N}$ fertilization were also observed by several authors ${ }^{7,21,22}$. We found that TDN was strongly associated with NFC, NDFpd, and soluble protein (Tables 1 and 2).

Neutral detergent fiber, indigestible detergent fiber, and potentially degradable detergent fiber. The concentration of NDF decreased linearly with increasing N levels $(P<0.001$; Table 1$)$. Conversely, there was a cubic relationship between NDF and year $(P<0.05$; Table 2). Our results corroborate other studies that found a reduction in NDF with increasing $\mathrm{N}$ fertilization ${ }^{4,7,21}$. Nitrogen fertilization can increase cell content and decrease the cell wall concentration ${ }^{28}$. However, this effect is climate-dependent, as observed in our study. Lower NDF concentrations occurred in 2016, when higher precipitation was observed (Fig. 1 and Table 2). Water availability in the soil is essential for $\mathrm{N}$ uptake by the plant. In the years that ocorred greater precipitation the conponents of cell wall descreased probably due increases in $\mathrm{N}$ recovery by the marandu palisade grass.

The iNDF concentration decreased linearly with increasing $\mathrm{N}$ fertilization $(P<0.01$; Table 1$)$. Few publications have reported iNDF concentrations. We presented this data because fiber is the most common variable used to predict the feed energy concentration, and there is a negative relationship between fiber concentration and available energy $\mathrm{y}^{31}$. The reduction in iNDF concentration due to increasing $\mathrm{N}$ fertilization suggests that high $\mathrm{N}$ fertilization is a potental strategy to increase available energy in tropical grasses under grazing. However, this reduction was observed when the pasture was managed under a light interceptation level of $95 \%$, which limited stem elogantion. Different results may occur in other forage management strategies ${ }^{26}$.

The $\mathrm{N}$ fertilization had a quadratic effect on NDFpd $(P<0.05$; Table 2$)$. The reduction of NDFpd with the application of $\mathrm{N}$ occurred up to a dose of $180 \mathrm{~kg} \mathrm{~N} \mathrm{ha}^{-1}$. NDF provides energy for ruminal microbial syntheses, but also improves rumen function by adding structural carbohydrates to the ruminant diet ${ }^{32}$. The stabilization of the degradable fraction of NDF with increasing $\mathrm{N}$ fertilization suggests that the structural value, that is, the passage rate of ruminant diet, was maintained.

Acid detergent fiber. Increasing $\mathrm{N}$ fertilization had a negative linear effect on ADF concentration $(P<0.01$; Table 1). Previous research found that increasing $N$ fertilization had little or no effect on $\mathrm{ADF}^{7,29}$. There was a quadratic relationship between ADF concentration and experimental year $(P<0.05$; Table 2$)$. The plant cell wall concentration can vary due to variations in precipitation and temperature. Rainfall and temperature are the major factors that affect plant maturity. The combination of relatively cooler temperatures and the absence of rain well into the growing season can result in a forage reproductive state, which could increase the fiber fractions $^{2}$ and might explain these changes in ADF concentrations. The highest average ADF concentration (36.15\%) was observed during the growing season of 2018 when lower precipitation occurred (Fig. 1).

Total protein. A linear increase in $\mathrm{CP}$ concentration was observed with increasing $\mathrm{N}$ levels, and a linear relationship between $\mathrm{CP}$ and experimental year was observed $(P<0.001$; Tables 1 and 2$)$. Increases in CP concentrations of forage due to $\mathrm{N}$ fertilization are known. For example, Prine and Burton (1956) observed increases in $\mathrm{CP}$ as annual $\mathrm{N}$ fertilization levels increased in warm grasses. Similar results have been observed in other studies ${ }^{4,7,8,29}$. Additionally, we observed a cumulative effect of $\mathrm{N}$ fertilization on $\mathrm{CP}$ concentration over the duration of the experiment. Although forage $\mathrm{CP}$ concentrations can vary with precipitation and temperature ${ }^{28}$, the responses of $\mathrm{CP}$ to $\mathrm{N}$ fertilization observed could not be attributed to the climatic variables. The highest and lowest precipitation did not coincided with the experimental years that the highest and lowest $\mathrm{CP}$ concentrations occurred (Fig. 1 and Table 2).

The average CP concentration for Marandu palisadegrass is usually less than $10 \%{ }^{7,13,33}$. The minimum value observed in our study was $12 \%$ (Tables 1 and 2). Our results are similar to those found previously in our experimental site (11\%-14\%; Barbero et $\mathrm{al}^{25}$; Koscheck et al. $\left.{ }^{27}\right)$ and that observed by McRoberts et al. ${ }^{8}$, which was $13 \%-15 \%$. Nitrogen concentration, together with the cell wall concentration, is the most important factor in the supply of the required quantity of nutrients ${ }^{26}$. Our results suggest that five years of grazing at a fixed pasture height that corresponds to the $95 \%$ light interception during the growing season can result in high CP concentrations for Marandu palisadegrass, even without $\mathrm{N}$ fertilization. Therefore, a high animal performance could be obtained.

Soluble protein: Fraction A and B1. The fraction of soluble protein increased linearly with increasing N levels $(P<0.0001$; Table 1$)$ and with experimental year $(P<0.01$; Table 2$)$. Previous research ${ }^{8,21,22}$ has indicated that increased $\mathrm{N}$ fertilization levels increase nitrate accumulation in the plant, which is a portion of Fraction A.

The soluble protein fraction varied from 325 to $586 \mathrm{~g} \mathrm{~kg}^{-1} \mathrm{CP}$ throughout the experiment (Table 2). Several researchers have shown that the proportion of leaves and stems, leaf expansion rate, and tillering adapt to new grazing management targets ${ }^{24,34}$. In our study, the grazing management strategy allowed the growth of a greater proportion of green leaves, which probably explains the increase in soluble protein. High concentrations of Fraction $\mathrm{A}$ and $\mathrm{B} 1$ are desirable, as this fraction is rapidly degraded in the rumen and can result in greater animal performance ${ }^{35}$. Animal performance depends on microbial protein production that can be optimized with a greater amount of soluble $\mathrm{N}$ since the amount of energy does not limit microbial growth considering de NFC and NDFpd levels (Table 1). 


\begin{tabular}{|c|c|c|c|c|c|c|c|c|c|c|c|}
\hline \multirow[b]{2}{*}{ Year } & \multirow{2}{*}{$\begin{array}{l}\text { P resin } \\
-\mathrm{mg} / \mathrm{dm}^{3}-\end{array}$} & $\mathrm{S}-\mathrm{SO}_{4}{ }^{2-}$ & OM & $\mathrm{pH} \mathrm{CaCl}{ }_{2}$ & $\mathbf{K}^{+}$ & $\mathrm{Ca}^{2+}$ & $\mathrm{Mg}^{2+}$ & $\mathrm{H}^{+} \mathrm{Al}$ & $\mathrm{Al}^{3+}$ & CEC & V\% \\
\hline & & \multicolumn{2}{|l|}{$\mathrm{g} / \mathrm{dm}^{3}$} & \multicolumn{8}{|c|}{$--\mathrm{mmolc} / \mathrm{dm}^{3}--$} \\
\hline 2015 & 12 & 16 & 25 & 5,2 & 2,6 & 36 & 11 & 22 & 0 & 92 & 62 \\
\hline 2016 & 15 & 11 & 27 & 5,1 & 2,8 & 37 & 17 & 28 & 0 & 98 & 61 \\
\hline 2017 & 13 & 12 & 28 & 5,1 & 3,0 & 35 & 14 & 24 & 0 & 95 & 59 \\
\hline 2018 & 12 & 16 & 26 & 5,2 & 3,0 & 34 & 13 & 22 & 0 & 94 & 59 \\
\hline 2019 & 11 & 15 & 28 & 5,2 & 2,9 & 32 & 13 & 23 & 0 & 92 & 57 \\
\hline
\end{tabular}

Table 3. Means soil chemical caracteristcs of the experimental area at the depth of $0-20 \mathrm{~cm}$, JaboticabalSP. $\mathrm{P}=$ phospuros, $\mathrm{S}-\mathrm{SO}_{4}{ }^{2-}=$ sulfate, $\mathrm{OM}=$ organic matter, $\mathrm{K}=$ potassium, $\mathrm{Ca}=$ Calcium, $\mathrm{Mg}=$ magnesium, $\mathrm{Al}=$ alluminum, $\mathrm{CEC}=$ capacity os exchange cations and $\mathrm{V} \%=$ bases saturation.

Fractions B2 and B3. We did not find any effect of increasing $\mathrm{N}$ fertilization on the protein fractions with moderate and low degradation rates. Conversely, these fractions varied quadratically with experimental year $(P<0.01$; Table 2). Fraction B2 was approximately $40 \%$ lower during the fourth and fifth experimental years. The highest average value of Fraction B3 was observed in the year with the lowest precipitation (2016; Fig. 1). Fractions B2 and B3 are associated with membranes and extensins that are bound to hemicellulose and are dependent on the temperature. In our study, the temperature remained similar throughout the year, varying from 19 to $31^{\circ} \mathrm{C}$ (Fig. 1).

In contrast to our results, Fraction B2 has previously been found to vary with $\mathrm{N}$ fertilization. Rogers et al. ${ }^{20}$ found that Fraction B2 increased by approximately $35 \%$ in bermudagrass, and Johnson et al. ${ }^{21}$ observed an increase of up to $57 \%$ for warm-season grasses in Florida with $\mathrm{N}$ fertilization. Theses variations between theses studies and our findings is likely due to the pastures management differences. Berça et al. ${ }^{14}$ showed that pasture management play essential role in the variation of fiber concentration in marandu palisade grasss However, our results are in line with those of Santos et al. ${ }^{22}$, who only observed an effect of seasonality, with the highest values Fraction $\mathrm{B} 2$ being associated with low rainfall and high NDF.

Protein fraction C: non-degradable nitrogen. Fraction $\mathrm{C}$ decreased linearly with $\mathrm{N}$ fertilization $\left(P<0.01\right.$; Table 1). This result differs from previous studies. Johnson et al. ${ }^{22}$ observed that Fraction $\mathrm{C}$ depends of the $\mathrm{N}$ fertilization dose for bahiagrass and stargrass being lower or higher to the lowest dose. Rogers et al. ${ }^{20}$ and Santos et al. ${ }^{22}$ did not find any effect of $\mathrm{N}$ fertilization on Fraction C. However, similar to our results, Zhang et al. ${ }^{36}$ found a decrease in Fraction $\mathrm{C}$ by $55.3 \%$ in annual ryegrass forage with increasing $\mathrm{N}$ fertilization.

Fraction $\mathrm{C}$ corresponds to $\mathrm{N}$ linked with lignin, tannin-protein complexes, and Maillard products, which are highly resistant to enzymes produced by the microbes in the rumen, being considered unavailable to the animal ${ }^{10,11,17}$. Increasing $\mathrm{N}$ fertilization improved protein availability in Marandu palisadegrass. Growing Marandu palisadegrass under a grazing management strategy with a pasture height corresponding to a light interception of $95 \%$ resulted in a low concentration of structural carbohydrates associated with lignin and a low concentration of Fraction $\mathrm{C}^{25,27}$.

The crude protein:organic matter digestibility ratio increased linearly in response to $\mathrm{N}$ fertilization (Table 1). According to Poppi and McLennan ${ }^{37}$, a CP:DOM of 160 g resulted in high efficiency of microbial growth; however, CP:DOM values above $210 \mathrm{~g}$ caused high $\mathrm{N}$ losses. Maximum $\mathrm{N}$ utilization efficiency values in post-weaning beef cattle reared in tropical grass pasture were observed below $200 \mathrm{~g}$ of $\mathrm{CP} / \mathrm{kg} \mathrm{DOM}$, and losses occurred above $200 \mathrm{~g}$ of $\mathrm{CP} / \mathrm{kg} \mathrm{DOM}^{38}$. In the present study values above $160 \mathrm{~g}$ of $\mathrm{CP} / \mathrm{kg} \mathrm{DOM}$ were observed at doses of 180 and $270 \mathrm{~kg}$ of $\mathrm{N} / \mathrm{ha}$.

Conclusions. Estimations of carbohydrate and protein fractions can increase the nutrient utilization efficiency and determine the type of supplementation needed under each pasture management strategy. We observed an increase in $\mathrm{CP}$ and soluble protein with increasing $\mathrm{N}$ fertilization, leading to less protein being required in supplements. Therefore, it is necessary to include soluble carbohydrates, starch, and pectin in the diet to maintain protein and carbohydrate degradation synchrony in the rumen and optimize microbial growth. We observed higher CP, soluble protein, and TDN concentrations when $90 \mathrm{~kg} \mathrm{~N} \mathrm{ha}^{-1}$ was applied, suggesting that this dose is the most suitable for Marandu palisadegrass under a continyos stocking and a pasture management strategy with canopy target of $25 \mathrm{~cm}$ during the growing season. Future studies should be directed toward understanding undegradable protein supplementation, inclusion of proteins from legumes, and high degradable carbohydrate fractions in tropical diets.

\section{Methods}

Experimental area and design. We conducted a five-year experiment in the Forage and Grasslands Laboratory of São Paulo State University, "Julio de Mesquita Filho" (UNESP) (Jaboticabal, São Paulo, Brazil), during the summer growing seasons (December to April) of 2014/2015, 2015/2016, 2016/2017, 2017/2018, and $2018 / 2019$. The climate of the experimental area is classified as a subtropical humid climate, with wet summers and dry winters ${ }^{4}$. The mean annual rainfall is $1424 \mathrm{~mm}$, the mean air temperature is $22.3^{\circ} \mathrm{C}$, and the soil is a Rhodic Ferralsol derived from basalt ${ }^{39}$. The pasture was established in 2001 with Urochloa brizantha (Hochst ex A. Rich) Stapf Marandu (Marandu palisadegrass). The precipitation and temperature in the experimental area are presented in Fig. 1. During the growing season, the average minimum and maximum temperatures were 
$19{ }^{\circ} \mathrm{C}$ and $31^{\circ} \mathrm{C}$, respectively, and the average monthly sunlight varied from 150 to $300 \mathrm{~h}$. Mean soil chemical characteristics evaluated always on the September from 2015 to 2019 are presented in Table 3. In November of each year, maintenance fertilizer was applied to all paddocks at $50 \mathrm{~kg} \mathrm{P}_{2} \mathrm{O}_{5}$ (superfosfate) and $70 \mathrm{~kg} \mathrm{~K}_{2} \mathrm{O}$ (potassium chloride) per hectare. Soil texture content are $291,123,588 \mathrm{~g} \mathrm{~kg}^{-1}$ soil of clay, silte and sand, respectively.

The experiment consisted of four nitrogen doses $\left(0,90,180\right.$, and $\left.270 \mathrm{~kg} \mathrm{~N} \mathrm{ha}^{-1}\right)$ in a completely randomized design with three replicates per treatment, totaling 12 paddocks (experimental units). The paddock areas were $1.3 \mathrm{ha}, 1 \mathrm{ha}, 0.7 \mathrm{ha}$, and 0.5 ha for the treatments $0,90,180$, and $270 \mathrm{~kg} \mathrm{~N} \mathrm{ha}^{-1}$, respectively. The experimental area included a reserve area of 3 ha for the spare animals. The experimental area meets the criterion of soil homogeneity to conduct a CRD experiment. The source of $\mathrm{N}$ was urea, and its application was split across three times during the rainy season (Begin of December, end of January and begin of March). Animals used in research were cared for according to the rules of the São Paulo State University Animal Care and Use Committee and the National Council of Animal Experimentation Control. The committee reviewed and approved the experiment and all procedures carried out in the study (Certificate number 12703/15). We declare that no permissions or specific requirement to collect, analyse and work with Urochloa brizantha are requeride by local and national Brazilian authorities.

Grazing management. The present study was conducted under grazing conditions. Each year, 72 young Nellore bulls (Bos indicus) were used to measure animal productivity (average daily gain and gain per ha). The bulls had an initial body weight (mean \pm standard deviation) of $352 \pm 5 \mathrm{~kg}, 334 \pm 2 \mathrm{~kg}, 315 \pm 6 \mathrm{~kg}, 220 \pm 2 \mathrm{~kg}$, and $206 \pm 9 \mathrm{~kg}$ in the first, second, third, fourth, and fifth experimental years, respectively.

The experimental units were grazed with a continuous and variable stocking rate ${ }^{40}$. To maintain the pasture height, the stocking rate was adjusted weekly. The grazing target was a pasture height of $25 \mathrm{~cm}$. At this height, the canopy intercepted $95 \%$ of the incident light under our experimental conditions. At this light interception, the maximal net forage accumulation is achieved, resulting in high average daily gain and gain per hectare ${ }^{24,25,27}$.

Forage collection and preparation. Forage samples were harvested at 28 - $d$ intervals beginning in the middle of December from 20 points per hectare using the hand-plucking method ${ }^{41}$. In the hand-plucked method the grazing behavior of the animal is firstily observed ; then herbage samples are taken manualy mimicking the animal foraging. Approximately $200 \mathrm{~g}$ of fresh matter was harvested per sample to determine forage chemical compositions. Samples were dried in a forced-air oven $\left(55 \pm 5^{\circ} \mathrm{C}\right.$, for $\left.72 \mathrm{~h}\right)$, ground in a mill through a $2-\mathrm{mm}$ screen (Thomas-Wiley Laboratory Mill Model 4, H. Thomas Co.), and taken to the laboratory for analysis.

Chemical analysis. Laboratory analyses included measurements of dry matter (DM), organic matter (OM), and ash determined using the following procedures from $\mathrm{AOAC}^{42}$ : AOAC 934.01 for DM, AOAC 942.05 for OM, and AOAC 942.05 for ash. Crude protein (CP) concentration (AOAC 990.03) was estimated using a LECO FP 528 device (Leco Corporation, Michigan, USA). Neutral detergent fiber (NDF) and acid detergent fiber (ADF) were determined using the procedures described by ANKOM Technology ${ }^{43}$.

The indigestible neutral detergent fiber (iNDF) was quantified by in situ incubation of hand-plucked samples conditioned in ANKOM brand F-57 filter bags arranged in the rumen of fistulated animals for $288 \mathrm{~h}^{44}$. After being thoroughly washed, oven-dried at $55^{\circ} \mathrm{C}$ for $72 \mathrm{~h}$, and then dried in an unventilated oven at $105{ }^{\circ} \mathrm{C}$ for $45 \mathrm{~min}$, the bags were weighed to obtain the indigestible DM. Subsequently, the bags were subjected to NDF quantification using the ANKOM fiber analyzer, as cited above.

Fractions of forage carbohydrates were obtained following Sniffen et al. ${ }^{17}$ for total carbohydrates (TC) and non-fibrous carbohydrates (NFC). Total digestible nutrient (TDN) was calculated using the equation of energy using multiple components ${ }^{31}$. The potentially degradable NDF (NDFpd) was calculated by subtracting iNDF from the NDF.

The fractionation of protein was determined as described by Sniffen et al. ${ }^{17}$. Fraction A was obtained by extracting the soluble $\mathrm{N}$ using trichloroacetic $\operatorname{acid}^{45}$ and calculating the difference between the total $\mathrm{N}$ concentration and the non-protein nitrogen ${ }^{17}$. For quantification of buffer soluble protein (Fractions A and B1), $0.50 \mathrm{~g}$ of sample was extracted with $50 \mathrm{~mL}$ of borate-phosphate buffer and $1 \mathrm{~mL}$ of sodium azide solution. Fraction B2 was calculated by subtracting Fraction A, Fraction B1, and the neutral detergent insoluble protein (N-NDF) from the total N. Fraction B3 was the difference between the N-NDF and the acid detergent insoluble protein $(\mathrm{N}-\mathrm{ADF})$. Fraction $\mathrm{C}$ was the $\mathrm{N}-\mathrm{ADF}^{17}$. All fractions were expressed and $\mathrm{g} \mathrm{kg}^{-1} \mathrm{CP}$.

Statistical analysis. Data were analyzed using the LME function of R for mixed models (package NLME, $\mathrm{R}$ version 3.4.5). The statistical model included $\mathrm{N}$ level, year, and their interaction as fixed effects, and paddock was a random effect. All variables were analyzed as repeated measures. The best covariance structure used for repeated measures was chosen as the one that achieved the lowest corrected Akaike or Bayesian information criteria. The statistical model was:

$\gamma \mathrm{ijk}=\mu+\alpha \mathrm{i}+\pi \mathrm{j}(\mathrm{i})+\beta \mathrm{k}+\alpha \beta \mathrm{ik}+\varepsilon \mathrm{ijk}$, where: $\gamma \mathrm{ijk}$ is the observation, $\mu$ is the overall mean, $\alpha$ is the fixed effect of $\mathrm{N}$ doses, $\pi \mathrm{j}(\mathrm{i})$ is the random error associated with the $\mathrm{N}$ doses and repetitions, $\beta \mathrm{k}$ is the fixed effect of year (time), $\alpha \beta \mathrm{ik}$ is the $\mathrm{N}$ doses by year interaction and cijk equals the residuals error.

When a significant effect was found, orthogonal polynomial contrasts were performed to assess the effects of $\mathrm{N}$ level and year on the variables.

\section{Data availability}

Data will be made available upon request for authors. 
Received: 16 March 2021; Accepted: 6 July 2021

Published online: 20 July 2021

\section{References}

1. Singh, P. Tropical grasslands-trends, perspectives and future prospects. 1-14 (FAARD Foundation, 2019)

2. Nascimento, H. L. B. et al. Herbage accumulation, canopy structure and tiller morphology of marandu palisadegrass growing in open pasture and in silvopasture. Agrofor. Syst 95, 1-14 (2021).

3. Alencar, N. M. et al. Herbage characteristics of pintoi peanut and paslisadegrass established as monoculture or mixed swards. Crop Sci. 58, 2131-2137 (2018).

4. Delevatti, L. M. et al. Effect of nitrogen application rate on yield, forage quality, and animal performance in a tropical pasture. Sci. Rep. 9, 1-9 (2019).

5. Prine, G. M. \& Burton, G. W. The effect of nitrogen rate and clipping frequency upon the yield, protein concentration and certain morphological characteristics of Coastal bermudagrass (Cynodon dactylon (L) Pers.). Agron. J. 48, 296-301 (1956).

6. Peyraud, J. \& Astigarraga, L. Review of the effect of nitrogen fertilization on the chemical composition, intake, digestion and nutritive value of fresh herbage: consequences on animal nutrition and N balance. Anim. Feed Sci. Technol. 72, 235-259 (1998).

7. Dupas, E. S. et al. Nitrogen recovery, use efficiency, dry matter yield, and chemical composition of palisade grass fertilized with nitrogen sources in the Cerrado biome. Aust. J. Crop Sci. 10, 1330 (2016).

8. McRoberts, K. C. et al. Urea and composted cattle manure affect forage yield and nutritive value in sandy soils of south-central Vietnam. Grass Forage Sci. 73, 132-145 (2018).

9. National Academies of Sciences, Engineering, and Medicine (NASEM) Nutrient requirements of beef cattle (8th revised edition) 200-2005 (The National Academies Press, 2016)

10. Tedeschi, L. O., \& D. G. Fox. The ruminant nutrition system: volume I - an applied model for predicting nutrient requirements and feed utilization in ruminants. (3rd ed.) 1-150 (XanEdu, 2020a)

11. Tedeschi, L. O., \& D. G. Fox. The ruminant nutrition system: volume II - tables of equations and coding. (3rd ed.) 88-102 (XanEdu, 2020b)

12. Elizalde, J. C., Merchen, N. R. \& Faulkner, D. B. Fractionation of fiber and crude protein in fresh forages during the spring growth. J. Anim. Sci. 77, 476-484 (1999).

13. Paciullo, D. S. C., Gomide, J. A., Queiroz, D. S. \& Silva, E. A. M. D. Chemical composition and in vitro digestibility of leaf blades and stems of forages grasses, according to level of insertion on grass tiller, age and season of growth. Ver. Bras. Zootec. 30, 964-974 (2001).

14. Berça, A. S. et al. Protein and carbohydrate fractions in warm-season pastures: effects of nitrogen management strategies. Agronomy 11, 847 (2021).

15. Fox, D. G., Sniffen, C.J., O’Connor, J.D., Van Soest, P.J. \& Russell. J.B. A net carbohydrate and protein system for evaluating cattle diets III Cattle requirements and diet adequacy. J. Anim. Sci. 70, 3578 (1992).

16. Russell, J. B., O’Connor, J.D., Fox, D.G., Van Soest, P.J. \& C. J. Sniffen, C.J. A net carbohydrate and protein system for evaluating cattle diets. I. Ruminal fermentation. J. Anim. Sci. 70, 35-51 (1992)

17. Sniffen, C. J., O'Connor, J.D., Van Soest, P.J., Fox, D.G. \& Russell. J.B. A net carbohydrate and protein system for evaluating cattle diets. II. Carbohydrate and protein availability. J. Anim. Sci. 70, 35-62 (1992).

18. O'Connor, J. D., Sniffen, C.J., Fox, D.G. \& Chalupa, W. A net carbohydrate and protein system for evaluating cattle diets. IV. Predicting amino acid adequacy. J. Anim. Sci. 71, 1298 (1993).

19. Tedeschi, L. O. Mathematical modeling in ruminant nutrition: approaches and paradigms, extant models, and thoughts for upcoming predictive analytics. J. Anim. Sci. 97, 1321-1944 (2019).

20. Rogers, J. R., Harvey, R.W., Poore, M.H., Mueller, J.P., \& Barker. J.C. Application of nitrogen from swine lagoon effluent to bermudagrass pastures: seasonal changes in forage nitrogenous constituents and effects of energy and escape protein supplementation on beef cattle performance. J. Anim. Sci. 74, 1126-1133 (1996).

21. Johnson, C. R., Reiling, B. A., Mislevy, P. \& Hall, M. B. Effects of nitrogen fertilization and harvest date on yield, digestibility, fiber, and protein fractions of tropical grasses. J. Anim. Sci. 79, 2439-2448 (2001).

22. Santos, C. B., Costa, K. A. D. P., Souza, W. F. D., Epifanio, P. S. \& Santos, H. S. Protein and carbohydrates fractionation in Paiaguas palisadegrass intercropped with grain sorghum in pasture recovery. Acta Sci. 41, 1-8 (2019).

23. Carneiro, B., Pedreira, C.G.S. \& da Silva, S.C. 2007. Estrutura do dossel e acúmulo de forragem de Brachiaria brizantha cultivar Xaraés em resposta a estratégias de pastejo. Pesqui. Agropecu. Bras. 42, 281-287 (2007).

24. Santana, S. S. et al. Canopy characteristics and tillering dynamics of Marandu palisade grass pastures in the rainy-dry transition season. Grass Forage Sci. 72, 261-270 (2016).

25. Barbero, R. P. et al. Combining Marandu grass grazing height and supplementation level to optimize growth and productivity of yearling bulls. Anim. Feed Sci. Technol. 209, 110-118 (2015).

26. Cardoso, A. S. et al. Intensification: a key strategy to achieve great animal and environmental beef cattle production sustainability in Brachiaria grasslands. Sustainability 12, 6656 (2020).

27. Koscheck, J. F. W. et al. How do animal performance and methane emissions vary with forage management intensification and supplementation?. Anim. Prod. Sci. 38, 1-11 (2020).

28. Van Soest, P. J. Nutritional ecology of the ruminant. 234-301 (Cornell University, 1994).

29. Di Loreto, R., J. et al. Nitrogen fertilization of Marandu palisadegrass under different periods of deferment. J. Exp. Ag. Int. 34, 1-8 (2019).

30. Oelberg, K. Factors affecting the nutritive value of range forage. J. Rangeland Manag. 9, 220-225 (1956).

31. Weiss, W. P. Predicting energy values of feeds. J. Dairy Sci. 76, 1802-1811 (1993).

32. Mertens, D.R. Regulation of feed intake. In: Forage quality, evaluation and utilization. (G. C. Fahey, J. M. Collins, D. R. Mertens, and L. E. Moser, editors) 450-493 (American Society of Agronomy, Crop Science Society of America, Soil Science Society of America, 1994).

33. Cardoso, A. S. et al. Seasonal effects on ammonia, nitrous oxide, and methane emissions for beef cattle excreta and urea fertilizer applied to a tropical pasture. Soil Tillage Res. 194, 104341 (2019).

34. Sollenberger, L. E., Moore, J.E., Allen, V.G. \& C. G. Pedreira, C.G. Reporting forage allowance in grazing experiments. Crop Sci. 45, 896-900 (2005).

35. Ruggieri, A.C. et al. Grazing Intensity impacts on herbage mass, sward structure, greenhouse gas emissions, and animal performance: analysis of brachiaria Pastureland. Agronomy-Basel 10, 1750 (2020).

36. Zhang, Y., Bunting, L.D., Kappel, L.C. \& Hafley, J.L. 1995. Influence of nitrogen fertilization and defoliation frequency on nitrogen constituents and feeding value of annual ryegrass. J. Anim. Sci. 73, 2474-2482 (1995).

37. Poppi, D. P. \& McLennan, S. R. Protein and energy utilization by ruminants at pasture. J. Anim. Sci. 73, 278-290 (1995).

38. Detmann, E., Valente, E.E.L., Batista, E.D. \& P. Huhtanen. P. An evaluation of the performance and efficiency of nitrogen utilization in cattle fed tropical grass pastures with supplementation. Livest. Sci. 162, 141-153 (2014).

39. Cardoso, A.S., Junqueira, J.B., Reis, R.A., \& Ruggieri, A.C. How do greenhouse gases vary with biofertilizer type, soil temperature, and moisture in a tropical grassland?. Pedosphere 30, 1-11 (2020). 
40. Mott, G. O. \& H. L. Lucas, H.L. The design, conduct and interpretation of grazing trials on cultivated and improved pastures. In International grassland congress. 1380-1395 (Pennsylvania State University, 1952).

41. Halls, L. K. The approximation of cattle diet through herbage sampling. Rangel. Ecol. Manag. 7, 269-270 (1954).

42. AOAC. 2012. Official methods of analysis of AOAC international. 19th ed. Assoc. Off. Anal. Chem., Arlington, VA. http://www. aoac.org (Accessed February 15, 2020)

43. Vogel, K. P., Pedersen, J.F., Masterson, S.D. \& J. J. Troy, J.J. Evaluation of a filter bag system for NDF, ADF and IVDMD forage analysis. Crop Sci. 39, 276-279 (1999).

44. Valente, T. N. P., Detmann, E., Queiroz, A.C.D., Valadares Filho, S.D.C., Gomes, D.I., \& J. F. Figueiras, J.F. Evaluation of ruminal degradation profiles of forages using bags made from different textiles. Ver. Bras. de Zootec. 40, 2565-2573 (2011).

45. Licitra, G., Hernandez, T.M. \& P. J. Van Soest, P. J. Standardization of procedures for nitrogen fractionation of ruminant feeds. Anim. Feed Sci. Technol. 57, 347-358 (1996).

\section{Acknowledgements}

The authors thank the members of UnespFor (Unesp Jaboticabal Forage Team) for their contributions during the field trial setup. This work was supported by the Fundação de Amparo à Pesquisa do Estado de São Paulo (FAPESP, grants 2015/04566-4; 2015/16631-5; 2016/20485-7; 2017/11274-5); the Coordenação de Aperfeiçoamento de Pessoal de Nível Superior (CAPES); and the Conselho Nacional de Desenvolvimento Científico e Tecnológico (CNPq, grant 431713/2018-9).

\section{Author contributions}

RGL, ASC, LOT, and RAR designed the research. LMD, RGL, NVBF, ACR, and MLCS conducted the field experiments and analyses. ASC analysed the data. ASC and RAR wrote the paper. All authors discussed the results and approved the manuscript.

\section{Competing interests}

The authors declare no competing interests.

\section{Additional information}

Correspondence and requests for materials should be addressed to A.d.C.

Reprints and permissions information is available at www.nature.com/reprints.

Publisher's note Springer Nature remains neutral with regard to jurisdictional claims in published maps and institutional affiliations.

(c) (i) Open Access This article is licensed under a Creative Commons Attribution 4.0 International License, which permits use, sharing, adaptation, distribution and reproduction in any medium or format, as long as you give appropriate credit to the original author(s) and the source, provide a link to the Creative Commons licence, and indicate if changes were made. The images or other third party material in this article are included in the article's Creative Commons licence, unless indicated otherwise in a credit line to the material. If material is not included in the article's Creative Commons licence and your intended use is not permitted by statutory regulation or exceeds the permitted use, you will need to obtain permission directly from the copyright holder. To view a copy of this licence, visit http://creativecommons.org/licenses/by/4.0/.

(C) The Author(s) 2021 